\title{
Produção de fanfictions e escrita colaborativa: uma proposta de adaptação para a sala de aula
}

\author{
Ana Elisa Ribeiro* \\ Lucas Mariano de Jesus**
}

\begin{abstract}
Resumo
Considerada uma das práticas sociais de leitura e escrita contemporâneas, a produção de fanfiction ou ficção de fã é nosso objeto de estudo neste artigo, que aborda também questões como a das práticas de escrita colaborativa, os desafios impostos ao debate no campo literário e a adaptação de parte dessas práticas para o ambiente escolar. A fim de testar esta última possibilidade, propôsse um curso a estudantes universitários de uma instituição federal de ensino (na área de Letras), no qual foram criadas oportunidades de escrita colaborativa de contos, empregando uma dinâmica semelhante à das fanfics. Nossas conclusões apontam para uma recepção positiva dos estudantes quanto à escrita colaborativa, o que pode alterar suas performances de escrita no sentido de um maior engajamento.
\end{abstract}

Palavras-chave: Escrita colaborativa. Produção de textos. Tecnologias digitais da informação e da comunicação. Fanfictions.

\section{Producción de fanfictions y escrita colaborativa: una propuesta de adaptación para clases de lengua \\ Resumen}

Considerada una de las prácticas sociales contemporáneas de lectura y escrita, la produción de fanfictions o ficciones de fans es nuestro objeto de estudio en este artículo, que aborda también questiones como las de las prácticas de escrita colaborativa, los desafíos impuestos al debate en el campo literário y la adaptación de parte de estas prácticas para el ambiente escolar. Con el objetivo de testar esta última posibilidad, hemos propuesto un taller a estudiantes universitários de una instituición federal de enseñanza (en el campo de las Letras) en lo cual se crearon oportunidades de escrita colaborativa de cuentos, empleando una dinámica similar a la de las fanfics. Nuestras conclusiones indican una recepción positiva de los estudiantes en relación a la escrita colaborativa, lo que puede cambiar sus performances de escrita en el sentido de una major implicación en la actividad.

Palabras-clave: Escrita colaborativa. Producción de textos. Tecnologías de la información y la comunicación. Fanfictions.

Recebido:20/03/2019

Aceito: 12/07/2019

\footnotetext{
* Centro Federal de Educação Tecnológica de Minas Gerais (CEFET-MG). Doutora em Linguística Aplicada pela Universidade Federal de Minas Gerais. Professora do Departamento de Linguagem e Tecnologia, do Bacharelado em Letras (Tecnologias da Edição) e do Programa de Pós-Graduação em Estudos de Linguagens do CEFET-MG.

** Centro Federal de Educação Tecnológica de Minas Gerais (CEFET-MG). Licenciado em Letras pela Universidade Federal de Lavras (UFLA). Pesquisador e Mestre em Estudos de Linguagens pelo Centro Federal de Educação Tecnológica de Minas Gerais (CEFET-MG).
} 


\section{Sobre letramentos e a contemporaneidade}

O acelerado desenvolvimento tecnológico de nosso tempo provoca mudanças socioculturais, o que inclui novas práticas de letramento, ao passo que as práticas "consolidadas" passam por transformações (FERRAREZI, 2015). Nesse contexto, os cidadãos devem ser capazes de agir, ter percepções próprias e interagir em relação a acontecimentos que interferem em suas vidas, local ou globalmente. Ler e escrever são modos e meios de fazer isso e, em nossa sociedade grafocêntrica, são atividades fundamentais também para o efetivo exercício da cidadania e a ampliação de possibilidades de participação nas interações sociais. Os estudos do letramento, em geral, se preocupam com os aspectos e as relações aqui mencionados. Neste artigo, os novos estudos do letramento informarão nossa mirada sobre a produção textual em novos contextos, tomando como base Gee (2000) e Lankshear (1999), para os quais é necessária uma abordagem sociocultural do letramento.

Algumas noções mais amplas são relevantes aqui, dentre elas a de "eventos de letramento", que, segundo Lopes (2004, p. 47), "podem desenvolver-se numa sequência de ações e envolver apenas uma pessoa ou um grupo delas, seja para elaborar uma peça escrita ou para ler alguma previamente produzida". As ficções de fã nos parecem, então, eventos de letramento muito contemporâneos. Já as "práticas de letramento" não se restringem a uma situação em particular, referindo-se à maneira como determinado grupo faz uso da escrita e de outras linguagens. Soares (2003, p. 105) define práticas de letramento como "comportamentos exercidos pelos participantes em um evento de letramento, onde as concepções sociais que o configuram determinam sua interpretação e dão sentido aos usos da leitura e/ou escrita naquela situação particular".

Segundo Lankshear e Knobel (2003), os novos estudos do letramento significam não apenas uma "nova forma de olhar" para o fenômeno do letramento, mas também um "olhar para as novas formas de letramento". Estas surgem à medida que precisamos nos engajar em eventos de letramento cada vez mais modernos e diversificados. São "novos" por conta de suas características e sua forma de existir, mas também são cronologicamente novos, pois surgiram depois que os estudos anteriores de letramento foram desenvolvidos, em especial aqueles que tomavam como objeto os letramentos escolares.

Estudos como os de James Paul Gee (2000; 2003) mostram como novas formas de aprendizagem podem contribuir para fomentar os letramentos. O autor trata de jogos digitais variados, incluídos jogos de violência, ação, aventura, simuladores e computadores. Jogos que, num primeiro momento, não foram criados com objetivos didáticos, mas que podem contribuir em contextos educacionais. Lankshear e Knobel $(2003 ; 2006$; 2011) nos lembram que os novos letramentos envolvem diferentes maneiras de atuar e pensar, resultantes das novas mídias, isto é, não apenas o uso de novos suportes ou mídias, mas também rupturas com as formas convencionais de ler o mundo e de atuar nele. Essas diferentes maneiras de atuar abarcam a criação de conteúdo pelo público amador e os novos tipos de engajamento em relação aos conteúdos que circulam na mídia, como os participativos, colaborativos e distribuídos, característicos da prática de escrever fanfictions, nosso objeto inspirador aqui. Nesse sentido, um ponto que diferencia os novos letramentos de outras perspectivas teóricas não é simplesmente a utilização das novas tecnologias, mas a existência de um novo ethos em seu manejo (LANKSHEAR; KNOBEL, 2011).

À luz do arcabouço conceitual aqui brevemente apresentado, o objetivo da pesquisa que ora relatamos foi experimentar em que medida uma dinâmica de escrita colaborativa (EC) inspirada nas fanfictions poderia contribuir para o letramento de um grupo de estudantes, especialmente por meio da proposta de produção de textos do gênero conto literário, no curso de Letras de uma instituição pública federal, em Belo Horizonte, MG. Para melhorar os contornos deste relato, passamos à discussão sobre fanfictions. 


\section{Das ficções de fã}

As fanfictions ou ficções de fã podem ser definidas como narrativas escritas, editadas e publicadas por fãs, em ambientes digitais. Elas são uma das formas que os fãs encontraram de se relacionar com seus favorites characters $^{1}$ e com outros fãs. Tais narrativas não têm intenção prévia de lucro financeiro ou de quebra de direitos autorais das obras em que são inspiradas. Além de prolongarem ou recriarem algum enredo original já existente, mesclam e exploram possibilidades de aglutinação de personagens, cenários de histórias distintas e ícones que fazem parte tanto da cultura pop, quanto do cânone literário. As fanfictions são elaboradas a várias mãos, produzindo uma espécie de autoria fluida. Um fã-autor, por exemplo, é coautor, crítico e leitor de várias outras histórias. Essa fluidez também reside na diversidade de categorias presentes no ambiente de circulação das fanfictions, que permite que os fãs tenham diversidade maior de tipos, extensão, características textuais e temáticas.

A quantidade de trabalhos realizados no Brasil sobre fanfiction aumentou, em especial nos últimos oito anos. Uma busca pelo termo no Google Scholar revela que pesquisadores brasileiros vêm lançando um olhar para as produções feitas por fãs. Miranda (2009), Piva e Affini (2015) e Clemente (2016), por exemplo, defendem a ideia de que a fanfiction surgiu das interações contínuas dos fãs de ficção em salas de bate-papo, redes sociais on-line e plataformas de armazenamento de narrativas de ficção. Para os autores que defendem essa ideia, a forma de produção de fanfictions é um aspecto crucial para defini-las como gênero digital, tendo em vista que são uma nova forma de leitura e escrita, em processos espontâneos de criação compartilhada, o que favorece a construção de saberes individuais e coletivos (COSTA; BULHÕES-CAMPOS, 2013). Esses “processos espontâneos" se constituem como parte do contexto de produção das fanfictions e do modo como os sujeitos compreendem as atividades de leitura e escrita voltadas para a publicação de suas histórias. Outra questão importante seria a leitura multimodal e hipertextual das fanfictions, tendo em vista que elas são narrativas constituídas por imagens, textos verbais, vídeos e outras linguagens.

Por outro lado, Jenkins (1992) defende que a origem das fanfictions está estritamente ligada ao campo do fandom, ou seja, espaço em que a coletividade tem papel crucial. Em consonância com essa ideia, Miranda afirma:

Se o leitor individualizado no mundo real sujeita-se a receber/perceber o cânon institucionalizado respeitando as normas e códigos que presidiram à sua sistematização, o leitor coletivizado do fandom apresenta-se muito mais independente, selecionando não só o seu cânon particular como estabelecendo novas regras para a recepção/percepção da obra literária, incluindo estratégias de leitura produtiva e criativa através dos mais diversos recursos tecnológicos disponíveis no ciberespaço. (MIRANDA, 2009, p. 1).

Jenkins (2015) afirma que o fandom organizado é, talvez, acima de tudo, uma instituição de teoria e crítica, um espaço semiestruturado no qual interpretações concorrentes e avaliações de textos comuns são propostas, debatidas e negociadas, e em que os leitores especulam quanto à natureza da mídia de massa e sua própria relação com ela. Para essa vertente, a circulação e o nascimento desses textos se deram, a princípio, por intermédio de um discurso que alimentou também o nascimento dos fanzines, que, até hoje, funcionam como um suporte para que os fãs possam se expressar de forma criativa. Segundo Lacerda (2008), os Estados Unidos são o país onde começou a história das fanatic magazines (o termo fanzine só começou a ser usado em 1941) e essas primeiras publicações foram organizadas por clubes de fãs do gênero ficção científica. Assim, o autor define os fanzines como:

1 A tradução literal para favorites characters é "personagens favoritos", porém o termo characters, no contexto das fanfictions, ganha um significado mais amplo e pode ser usado para se referir a uma canção ou a um jogo de videogame, por exemplo. 
Produções independentes que vão de encontro a qualquer censura, pregando a liberdade de expressão, abrindo espaço para todo tipo de comentários e opiniões, sobre as mais variadas temáticas e visões. Uma das mais marcantes características desse tipo de publicação é que qualquer pessoa pode se tornar fanzineira, independentemente de seu nível cultural, social, ou intelectual, o que importa é ter vontade e disposição para criar, produzir, montar, divulgar e distribuir seus fanzines. Afinal, todo faneditor é o faz-tudo de suas publicações. (LACERDA, 2008, p. 1).

Para ele, a origem dos fanzines está ligada à insatisfação com o quadro persuasivo da comunicação de massa. Essa característica se assemelha muito ao que a fanfiction propõe: buscar interpretações diferentes para "algo já concluído". Então, como uma forma de transgredir e de interagir com pessoas que compartilham do mesmo sentimento, surgem tais manifestações, que recebem o rótulo de "alternativas".

Essa linha de pensamento sobre a fanfiction se sustenta em pilares que ora se distanciam, ora se aproximam, sendo um deles a self-publishing. Para Almeida e outros (2016, p. 8), trata-se da "publicação de um livro ou qualquer outra mídia sem o envolvimento de uma editora, o que causa a consequente desintermediação de um processo que existe há vários séculos". Claramente, a fanfiction é um tipo de self-publishing, assim como os fanzines. Entretanto, ela não pode ser considerada uma "evolução" destes, a circular em ambientes digitais. Como explica Jenkins (2015), há práticas diversas na produção dos fãs e é possível encontrar trabalhos voltados para a obra original, para criações independentes e ideias pessoais dos autores. Essa perspectiva tende a colocar o fã no centro da discussão sobre publicação, mercado editorial e comunicação. Com isso, é possível traçar um caminho para o avanço da figura do fã como produtor, receptor e multiplicador de conteúdos e deixar mais claras as ideias que assume essa vertente.

Ao ampliar ainda mais esse contexto, atualmente, é possível encontrar produções de fãs voltadas para games, animes, filmes, livros, bandas, cantores, etc. Grupos de fãs, ou seja, os fandoms, mobilizam-se e elegem ídolos e celebridades, reais ou ficcionais. Os fãs influenciam diretamente os modos como o objeto do seu fanatismo se propaga pela mídia e fora dela. Livros como Crepúsculo e Jogos vorazes, por exemplo, se tornaram filmes e movimentaram bilheterias mundo afora. A cantora Susan Boyle é outro exemplo: o vídeo de sua apresentação no Britains's Got Talent foi compartilhado em redes sociais por pessoas que tinham as ferramentas básicas necessárias para que o conteúdo se espalhasse. Não foi o reality show que a deixou famosa, mas a atuação de pessoas comuns. Só após a propagação do vídeo (legendado em várias línguas pelos fãs) é que a mídia mainstream ampliou, ainda mais, a visibilidade da desconhecida cantora.

O conhecimento particular e a habilidade cultural do leitor popular, dentro dos fandoms, promovem um processo de avaliação e interpretação crítica. Ao se envolverem com as práticas e os processos que fazem parte desse espaço, os fãs leitores e produtores colocam em funcionamento o exercício de uma competência popular que não é valorizada ou privilegiada em nenhum outro lugar. Na visão de Jenkins,

Os fãs costumam demonstrar uma atenção tão grande à particularidade das narrativas de televisão que chegam a envergonhar críticos acadêmicos. Nos domínios da cultura popular, os fãs são os verdadeiros experts; constituem uma elite educacional paralela, mesmo que não tenha reconhecimento oficial nem poder social. (JENKINS, 2015, p. 100).

Outra abordagem de estudos sobre a fanfiction trabalha com a noção de "literatura marginal", numa aproximação entre as fanfictions e os fanzines. Cruz (2008), por exemplo, levanta hipóteses sobre uma possível "prévia" do gênero fanfiction, apontando que escritos publicados no século XVII teriam fins alternativos para Dom Quixote de La Mancha, ou seja, uma narrativa baseada em outra narrativa. Dom Quixote foi lançado em duas partes: a primeira em 1605, e a segunda, 10 anos mais 
tarde. Nesse intervalo, Alonso Fernández de Avellaneda, pseudônimo usado pelo autor que publicou a continuação "não autorizada" da novela, criou sua versão utilizando personagens já construídos por Cervantes. Em tese, esse tipo de escrita se encaixaria bem na concepção básica do que se considera ser uma fanfiction, na atualidade.

As pesquisas que se propõem a compreender fanfictions como produções literárias marginais nos espaços virtuais estão fortemente ancoradas nos Estudos Culturais e na procura por novas formas do fazer literário. Essa discussão envolve, necessariamente, a consagração dos cânones e uma abertura para que produções periféricas encontrem lugar na discussão sobre literatura. Neves (2011) amplia isso quando aponta que a literatura, no contexto atual, requer novas propostas de construção e divulgação e que, nesse sentido, as noções de cultura e, consequentemente, de literatura têm seus parâmetros, e até mesmo sua função social, repensados.

Ademais, Oliveira (2015) lembra que é difícil delinear um marco para o começo da história dos estudos da cultura de fãs, mas é natural associá-lo ao desenvolvimento dos estudos culturais britânicos. Jenkins (1992, p. 1) se declara inspirado pela tradição da Escola de Birmingham, “que ajudou a reverter o desprezo público pelas subculturas da juventude, na medida em que queria construir uma imagem alternativa das culturas dos fãs, uma que visse os consumidores de mídia como ativos, criticamente engajados e criativos". Um dos aspectos mais importantes do estudo da cultura de fãs é o foco na audiência, no receptor dos produtos de mídias, e a concordância de que os consumidores de um produto de mídia podem ser ativos e participantes em outros campos, como o literário, por exemplo.

A discussão nesse cenário não é pacífica. Há muita resistência em admitir a emergência de novos paradigmas e determinar que posição essas novas textualidades devem ocupar. O ciberespaço e suas ciberliteraturas, como a fanfiction, estão, segundo Neves (2011, p. 161), "ampliando possibilidades na construção de um novo saber ou de um saber derivado, (re)construído como forma de questionamento da originalidade, do cânone e da autoria". A fanfiction, para esses teóricos, se constitui como uma literatura de resistência, de enfrentamento e de questionamento, na medida em que faz tentativas de deslocar o hegemônico e a autonomia autoral.

\section{Produção da fanfiction, práticas de escrita e escrita colaborativa}

Vamos aqui oferecer uma descrição mais objetiva do processo de escrita de fanfictions: ao dar início à sua história, um fã-autor procura outro fã para ajudá-lo na construção do texto. Essa ajuda é chamada de betagem, e o fã-colaborador é chamado de beta reader, que é um primeiro leitor ou avaliador do texto. A betagem ocorre antes de o texto ser publicado no site hospedeiro de fanfiction, e a relação entre o fã-autor e o beta reader é mediada por suportes variados. Quem escolhe o beta reader é o próprio fã-autor, e o que une os dois sujeitos é o fato de participarem do mesmo fandom, isto é, compartilharem o mesmo sentimento em relação ao mesmo objeto, sendo a relação entre eles, na maioria dos casos, amistosa. O mesmo fã-autor pode ser beta reader de outra história, pois os papéis de autoria, dentro de um fandom, principalmente nas fanfictions, são dinâmicos, e não há um autor absoluto, mas uma rede de autores, coautores, revisores e editores que assumem posturas diferentes, em momentos diferentes.

Após a publicação do primeiro capítulo da fanfiction (todas as narrativas são publicadas por capítulos, salvo aquelas que fazem parte do gênero one shot, que são histórias mais curtas, de capítulo único), os outros membros do fandom podem interagir com o texto, elogiando, criticando e, principalmente, sugerindo alterações. O fã-autor, após receber os comentários, decide quais alterações fazer, porém, como depende de uma audiência que o acompanhe e leia suas histórias, ele procura sempre "negociar" com o público e incorporar muitas das sugestões dadas. Dessa forma, as narrativas vão ganhando vida 
até serem finalizadas, num processo que demonstra aproximações com a EC.

A EC pode ser um processo no qual cada produtor interage e colabora na elaboração de um documento. A produção de um texto nesses moldes é um processo que exige confronto de ideias e negociação constante, já que a escrita está sob monitoramento. Pinheiro $(2011$, p. 4) afirma que, "dado seu caráter social, a colaboração tem como base outros conceitos, como socialização e confiança, identidade e coesão grupal, motivação e envolvimento ativo na participação". Castilho e outros (2007) alertam para o fato de que, nos tempos atuais, a escrita sai da dimensão da autoria individual para a dimensão da construção coletiva, em que conhecimentos e perspectivas se combinam para a criação de um trabalho mais rico, complexo e diversificado. Tais características estão em consonância com o que dizem Leandro, Weissheimer e Cooper (2013), ao salientarem que, ao trabalharem colaborativamente, os aprendizes são levados a refletir sobre o processo de (re)construção textual e priorizarem, assim, a orientação para o processo, com o produto final no segundo plano, livres da angústia de produzir um texto pronto já no início do processo.

Com o auxílio das Novas Tecnologias de Informação e Comunicação (NTIC) e, principalmente, com os recursos trazidos pela World Wide Web, as práticas de EC puderam ser aperfeiçoadas. A tecnologia wiki é um exemplo de EC com tecnologias digitais. Segundo Paiva (2014), wiki é um sistema de produção colaborativa de textos, em ambiente web, de forma cumulativa, ou seja, permite que diferentes autores participem do processo de criação dos textos, cujas edições podem ser alteradas e expandidas pelos usuários. A Wikipédia, famosa enciclopédia colaborativa, é um exemplo de plataforma wiki conhecida e muito acessada. Aqui, propomos uma aproximação entre o modo de produção de fanfictions e a EC. Dessa forma, tomamos a taxonomia proposta por P. Lowry, Curtis e M. Lowry (2004), que, com base nos trabalhos de Horton e outros (1991), propõem uma classificação dos possíveis processos de EC, em quatro eixos principais: Múltiplas Atividades de EC, Estratégias de EC, Papéis dos Participantes e Modos de EC.

As Múltiplas Atividades de EC são as que ocorrem durante o processo de elaboração de um texto em grupo. Elas perpassam desde a escolha do gênero e a coleta de informação sobre o que será escrito até a avaliação final do texto pelo grupo. Os autores ressaltam que essas atividades envolvem outras subdivisões, como rascunho, brainstorming, revisões iniciais, etc. As Estratégias de EC dizem respeito às formas como cada equipe decide conduzir a escrita, sendo as mais comuns:

Group single-author writing: uma única pessoa é responsável por escrever pelo grupo; comumente usada quando há um consenso entre os participantes sobre o que será escrito.

Sequential writing: cada membro do grupo escreve suas contribuições; alguém começa o texto e os outros inserem suas contribuições, até chegarem a um texto final, podendo haver falta de consenso sobre o que cada um escreveu e sobreposição de textos dos participantes subsequentes.

Parallel writing: o grupo divide o trabalho de escrita em unidades, para que cada membro trabalhe em paralelo, diferentemente da escrita em sequência, na qual os membros do grupo aguardam um texto inicial para dar sequência. Há maior autonomia dos participantes e, se for executada em conjunto com as ferramentas de comunicação síncrona e assíncrona existentes atualmente, os problemas de comunicação podem ser evitados.

Reactive writing: o texto a ser redigido é criado em tempo real e os participantes vão reagindo e editando o documento, de acordo com as contribuições que inserem no documento. Não há planejamento prévio e nem coordenação explícita. Pode envolver consenso, contradição, disputa e reflexão na elaboração do texto. São vantagens desse tipo a livre expressão por meio de um 
consenso construído e a criatividade gerada. As desvantagens são ausência de coordenação dos participantes e falta de consenso. O número de participantes nessa estratégia deve ser reduzido.

No processo de EC, de acordo com a taxonomia, tem-se vários papéis na escrita colaborativa, sendo os mais comuns: escritor (pode ser singular ou múltiplo e fica responsável por escrever o documento); consultor (fornece conteúdo para a escrita, mas não tem responsabilidade sobre a produção do conteúdo, sendo geralmente externo ao grupo); editor (tem responsabilidade sobre a produção e pode fazer alterações tanto de conteúdo, quanto de estilo); revisor (revisa o conteúdo e fornece feedbacks pontuais, podendo ser externo ao grupo); líder (deve fazer parte da equipe e participar completamente dos processos de revisão e planejamento); facilitador (conduz o grupo em processos apropriados, mas não dá retorno em relação ao conteúdo que o grupo está desenvolvendo, é externo ao grupo).

Em relação aos Modos de EC, temos quatro. Dependendo do local, do tempo, da proximidade e da sincronia com que as atividades são executadas, pode existir diferença no tipo de relação entre os participantes. Os quatro modos de EC podem influenciar ainda no que Moll (1996) chama de "consciência de grupo", que é experienciada por cada membro que compõe a equipe. Cada indivíduo desenvolve sua consciência de grupo ao compreender suas atividades com base na compreensão das atividades dos outros membros, assim, à medida que os modos de escrita colaborativa se alteram, a consciência de grupo também se altera.

Tomando como norte a taxonomia de P. Lowry, Curtis e M. Lowry (2004), é possível compreender que, nos processos de produção das fanfictions, as estratégias, os modos de produção, os papéis dos participantes e as atividades de escrita se misturam. Tal mistura não é prejudicial, no contexto de circulação dessas histórias ficcionais, tendo em vista que o próprio ambiente de circulação e as regras definidas pela comunidade que movimenta as fanfictions fazem parte de uma cultura mais fluida.

\section{Uma transposição para as práticas escolares e um percurso metodológico}

A produção de fanfictions tem forte relação com a EC. O que objetivamos aqui é criar uma oportunidade de escrita que possa transpor aspectos de uma prática on-line para o contexto escolar, levando em consideração as diferenças marcantes entre os dois cenários e tendo em mente que o que ocorre no ciberespaço pertence a esse ambiente e não pode ser transposto de forma exata para a sala de aula. Sendo assim, a artificialização de algumas práticas deve ser compreendida. Uma literatura que defende essa ideia entende as linguagens híbridas, os hipertextos e as interações que ocorrem no ciberespaço como potencializadores do ensino e da aprendizagem. Carvalho (2015) afirma que, dependendo da forma como os recursos são explorados, podem constituir um excelente meio para o desenvolvimento de diversas atividades. Isso condiz com o que Costa e Carvalho (2006) enfatizam, ao mencionarem a importância de se aproveitar o potencial que o computador e as novas tecnologias de informação e comunicação encerram, em termos de estímulo e suporte de aprendizagem. Práticas coletivas, como as de EC, são possibilidades de realizar tais encaminhamentos pedagógicos. Nesse sentido, Santana (2007) e Corcelles e outros (2017) afirmam que as práticas de EC assumem papel muito importante no desenvolvimento do pensamento reflexivo dos estudantes, nos vários níveis de ensino.

Pesquisas como a de Carvalho (2015), que teve o objetivo de elaborar um texto colaborativo em um ambiente virtual na Universidade Federal do Mato Grosso do Sul, evidenciam o potencial das estratégias de EC no Ensino Superior e alertam também para os seus limites. Segundo a pesquisadora, "ao realizar atividades com essas características, é perceptível a dificuldade de se trabalhar dentro de uma perspectiva dialógica” (CARVALHO, 2015, p. 7), mas que esse tipo de perspectiva é importante 
porque permite que os alunos, juntamente com o professor, tenham contato com novos modos de produzir textos.

O objetivo da pesquisa que ora relatamos, como já explicitado, foi experimentar em sala de aula uma dinâmica de EC inspirada nos processos de produção de fanfiction e verificar como ela pode contribuir para o desenvolvimento de textos do gênero conto literário, em especial com alunos de Letras. Eram profundos nosso interesse pelo universo das fanfictions e o desejo de estreitar dois contextos: o acadêmico e o de circulação das ficções de fã.

Leitura e escrita, bem como os processos de produção textual legitimados e realizados nas escolas de Educação Básica, e que se perpetuam no Ensino Superior, estão ligados a uma cultura tradicional, de práticas individuais (FARACO, 2009). O caráter colaborativo dos textos de fanfiction e as práticas de edição dos ficwriters, ${ }^{2}$ em que há um interlocutor que se interessa e dialoga com o outro, foram pontos de destaque no contexto da sala de aula empírica em que nos envolvemos. Buscamos, com este estudo de cunho qualitativo, uma forma de ressignificar posturas de produtores de textos, além do empoderamento dos sujeitos que se envolvem com tais atividades em sala de aula, favorecendo que participem de eventos de letramento cada vez mais elaborados. Repensar leitura e escrita, bem como a cultura fã, sob essa perspectiva, é também situar o letramento como parte de processos sociais mais amplos, nos quais a participação dos sujeitos no coletivo molda suas próprias estratégias e formas de produção, já que não basta saber ler e escrever, é preciso criticar o que se está lendo e reagir, na linguagem.

A dinâmica de EC proposta por esta investigação foi realizada em uma turma do curso de Letras de uma instituição pública federal de Belo Horizonte. Participaram nove alunos que cursavam uma disciplina optativa dedicada à discussão sobre tecnologias digitais, todos na etapa final da graduação. A maioria dos estudantes trabalhava durante o dia e estudava no período noturno. No início do curso, as aulas aconteciam em uma sala com lousa e carteiras. A segunda metade da disciplina aconteceu em laboratório de informática, o que nos deu suporte para o desenvolvimento das atividades.

O perfil dos estudantes era muito heterogêneo: tinham idades entre 23 e 53 anos e desempenhavam atividades remuneradas variadas. A maior parte já tinha a experiência de escrever textos literários e de outros gêneros além do conto, mas não de forma colaborativa. Apenas um dos alunos tinha vasta experiência com a escrita de textos literários. Todos demonstravam ter noção sobre algumas características do conto e conheciam autores renomados. Três estudantes já conheciam as fanfictions, bem como seus modos de produção, apesar de nunca terem escrito ou colaborado na criação de uma. Os demais não conheciam os modos de produção de escrever histórias ficcionais na internet.

A dinâmica de EC foi realizada por meio do Google Docs, mais especificamente do aplicativo Word Online, e Google Drive, serviço de armazenamento e sincronização de arquivos. Ribeiro (2011), ao fazer considerações sobre a EC e a ferramenta Google Docs, menciona que usá-la faz com que o escrever colaborativamente seja realizado com mais flexibilidade e controle sobre os processos de escrita, pois estes ficam mais visíveis e passíveis de acompanhamento. Discussões coletivas em grupo também fizeram parte de nossa dinâmica, oportunizando uma aproximação ao que de fato ocorre nos fandoms. Como forma de registrar impressões durante as discussões em grupo, um diário de campo foi por nós produzido durante as aulas.

Os repositórios mais populares de fanfictions foram adaptados para a sala de aula, sendo substituídos pelo Google Drive. Os ambientes de revisão dos textos e a realização da primeira betagem das narrativas foram reunidos na ferramenta Google Docs. As interações coletivas entre os fãs, após a publicação dos textos, tomaram a forma de rodas de discussão em sala de aula. A dinâmica teve início com cada estudante escrevendo um conto e compartilhando-o no Google Drive. Os textos poderiam estar "concluídos" ou não. Após esse primeiro passo, todos deveriam ler os contos e escolher um para

2 Termo usado para se referir aos escritores de fanfictions. 
desempenhar a função de leitor beta, ou seja, primeiro interlocutor da narrativa. Isso poderia ser feito de forma assíncrona.

Os alunos não foram orientados em relação ao tipo de intervenção que deveria ser realizada. Apresentamos apenas as ferramentas e o objetivo da dinâmica: construir os contos de forma colaborativa. Após a escolha do texto, o leitor beta foi de fato "betar" o conto, usando os recursos do Google Docs para comentar e sugerir modificações. Os autores, posteriormente, decidiriam quais modificações acatar até a última fase do processo.

Após os betas realizarem a primeira betagem, foram feitas discussões em grupo. Assim, dois ou três contos foram selecionados por aula, foram lidos previamente por todos, que poderiam fazer novas intervenções, de qualquer natureza, mas que deveriam ser expostas apenas no momento da discussão em sala. Assim, cada aluno fez sugestões, opinou e betou novamente os contos. Só após a discussão é que os autores puderam de fato entregar as "versões finais".

\section{Dos resultados da dinâmica com contos e escrita colaborativa}

Emergiram das produções colaborativas três categorias de intervenções textuais: textual, enredo e composicional. Foram elas que empregamos para a análise dos contos dos participantes do curso de Letras.

A intervenção "textual” é aquela geralmente relacionada à aplicação da gramática normativa. A categoria "enredo" é uma intervenção no conteúdo ou rumo da narrativa. A "composicional" toca elementos que compõem o gênero discursivo conto. O Quadro 1 mostra os resultados das intervenções nos textos, por categoria. Ao todo, 131 intervenções foram computadas, considerando que cada comentário, dica ou revisão feita pelo leitor beta, no segundo estágio da dinâmica, constitui-se como um dado para a construção deste quadro.

Quadro 1 - Categorias de intervenção

\begin{tabular}{|c|c|}
\hline Categoria da intervenção & Número de intervenções realizadas \\
\hline Textual & 106 \\
\hline Enredo & 5 \\
\hline Composicional & 20 \\
\hline Total & 131 \\
\hline
\end{tabular}

Fonte: Elaborado pelos pesquisadores.

Vejamos um exemplo típico das ocorrências durante o processo de EC proposto aos estudantes:

\section{Primeira versão}

Após formar em história, a moça passou a trabalhar em um museu e depois de três anos trabalhando lá, uma inquietação começava a se formar em seu interior. Talvez fosse aquele quadro.

Em um verão muito quente, o museu recebeu uma exposição de obras surrealistas, como curadora Laura passava grande parte do tempo com as obras. Dentre os vários pintores, estava Salvador Dalí, não que esse fato fosse importante pra ela, mas um quadro em particular lhe chamara a atenção. A Galarina. 


\section{Intervenção}

Após formar em história, a moça passou a trabalhar em um museu. Três anos se passaram e-e depois de três anos trabalhando lá,_uma inquietação começava a se formar em seu interior. Talvez fosse aquele quadro.

Em um verão muito quente, o museu recebeu uma exposição de obras surrealistas. Como- come curadora, Laura passava grande parte do tempo com as obras. Dentre os vários pintores, estava Salvador Dalí, não que esse fato fosse importante pra ela, mas um quadro em particular lhe chamara a atenção. A Galarina.

\section{Versão final}

Após formar em história, a moça passou a trabalhar em um museu. Três anos se passaram e uma inquietação começava a se formar em seu interior. Talvez fosse aquele quadro. Em um verão muito quente, o museu recebeu uma exposição de obras surrealistas. Como curadora, Laura passava grande parte do tempo com as obras. Dentre os vários pintores, estava Salvador Dalí, não que esse fato fosse importante pra ela, mas um quadro em particular lhe chamara a atenção. A Galarina.

\section{Fonte: Screenshots da interface.}

No exemplo, o leitor beta utilizou a ferramenta de revisão do Word para intervir, sendo a primeira e a segunda intervenções de tipo textual. As sugestões não alteram significativamente o sentido, mas foram acatadas pelo autor. Em outras intervenções, também há sugestões textuais, principalmente quanto à pontuação. Todos os casos mostram o predomínio de intervenções textuais, que ora higienizam, ora acrescentam expressões que não modificam a ordem nem o rumo dos acontecimentos.

Além das intervenções puramente textuais, há as de enredo e composicionais. Um exemplo é quando os betas sugerem que o autor seja mais claro em relação ao tempo durante o qual os acontecimentos se desenrolam na narrativa. Essa intervenção é realizada por meio de um comentário sobre a problemática do texto e revela também que o leitor beta busca um diálogo com autor. É apontado, por exemplo, o excesso de personagens na história.

O recurso do comentário também foi usado para realizar intervenções, como se pode verificar a seguir.
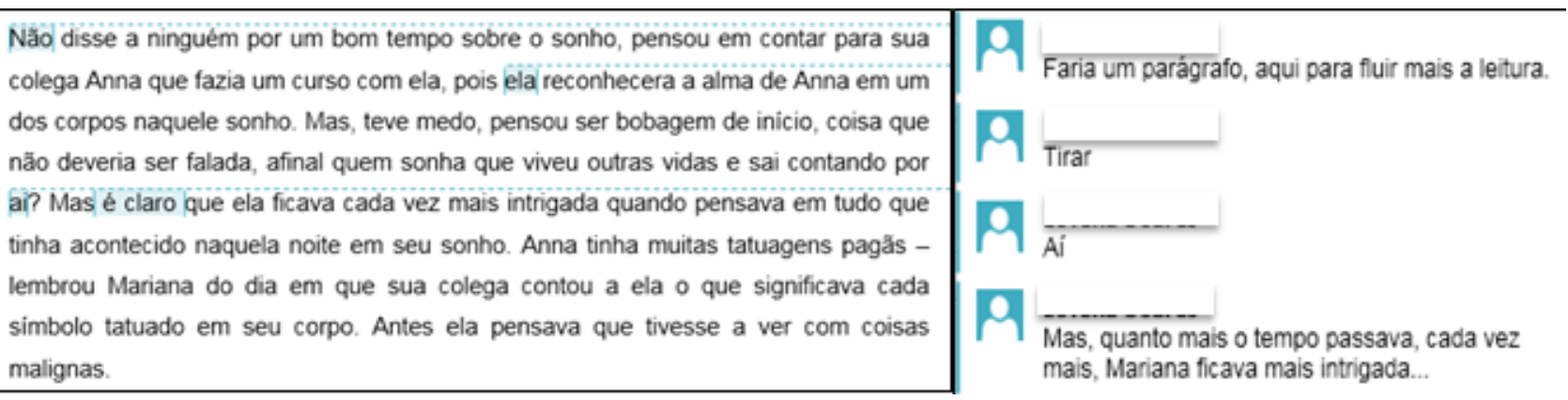

Fonte: Screenshot da interface.

Nesta etapa da dinâmica, os beta leitores se preocuparam muito mais com os aspectos linguísticos e formais do que com outros. Apesar de usarem ferramentas que propiciam intervenções diversificadas nos textos, como os comentários, houve predomínio do uso da ferramenta de revisão, o que reforça o caráter de intervenções puramente gramaticais. Apesar de não termos solicitado que os participantes fizessem esse tipo de correção, a intervenção e, de certo modo, a colaboração na narrativa do outro 
foram compreendidas dessa forma pela maioria. Isso pode ser explicado por uma prática, muito presente na Educação Básica, segundo a qual intervir em um texto é revisá-lo gramaticalmente, e não operar em outras dimensões. Embora isso tenha importância, é pouco, se comparado a aspectos como seleção vocabular, coesão e coerência discursivas (FERRAREZI, 2015). Quando passamos a examinar versões dos contos na íntegra, pudemos averiguar de que forma a etapa de discussão em grupo colaborou para o progresso de escrita dos contos. Os textos não serão disponibilizados aqui em razão do espaço deste artigo, mas pensamos que nosso relato possa dar uma boa ideia das ocorrências analisadas.

O conto “A 23 geração da família Von Doellinger" era a história de um casal prestes a ter o primeiro filho. A narrativa cria suspense, quando um tio do casal questiona o sexo da criança, insinuando algo de errado com o bebê. Depois disso, o casal se muda para a Finlândia, e o parto acontece. Então, o foco se volta para o nascimento, e o conto termina deixando a dúvida sobre o sexo do bebê que nasceu naquele dia. Esse foi o conto eleito para a primeira discussão em grupo. Em sua segunda versão, ele ainda não tinha um título, então os alunos sugeriram um. Caroline, ${ }^{3}$ a autora principal, anotou todas as sugestões. Depois disso, os estudantes quiseram saber sobre o sexo do narrador, que também é personagem da história. Esse tópico abriu espaço para uma discussão sobre como a autora deixou de marcar questões de gênero. Fizeram uma segunda leitura do conto, dessa vez procurando indícios que dessem respaldo à afirmação da neutralidade do narrador-personagem. Tal discussão durou alguns minutos, e os alunos concordaram que, ao finalizar a escrita, essa incógnita deveria ser mantida. Para finalizar a discussão, Lori ponderou: "Acho que esse conto merecia um final diferente". Caroline concordou e disse que iria reescrever o final da história.

As contribuições dos alunos na terceira etapa da dinâmica ultrapassaram os limites das intervenções gramaticais presentes na primeira betagem, feita individualmente. É interessante observar como o foco das intervenções mudou, no momento das discussões em grupo. O debate, inclusive sobre o sexo de personagens, instigou os alunos, e cada um queria dar sua opinião.

"A GaLarina", título do segundo conto, é sobre Laura, uma historiadora recém-formada que trabalha como curadora em um museu. A história narra um momento melancólico da protagonista, que se sente estagnada na vida, sem forças para sair da rotina. Esse quadro de melancolia se agrava com a chegada de obras surrealistas no museu e, mais especificamente, de um quadro de Salvador Dalí. Os acontecimentos que se seguem giram em torno da relação entre Laura e a obra. O conto se encaminha para o fim descrevendo a forma como Laura resolve o drama: "Em um ato súbito e definitivo, começou a rasgar a pintura e comê-la. Não havia outra solução, estava sendo sugada."

O conto "A GaLarina" chegou pela metade na terceira etapa da dinâmica, propiciando que a discussão girasse em torno da sua continuação. Os participantes faziam sugestões como "Ela poderia se apaixonar pelo quadro" ou "O que vocês acham de continuar com esse tom de mistério?". Ficaram interessados pelo tema, mas a autora não deu muitos feedbacks em relação às sugestões. Na discussão desse conto, foi possível perceber também que as intervenções relacionadas a aspectos meramente gramaticais foram deixadas de lado. O movimento de discutir e acrescentar trechos ao conto partiu da turma, e não da primeira autora. Apesar do pouco interesse da autora principal, os alunos não deixaram de discutir o texto e tomaram para si a responsabilidade de finalizá-lo. Embora tivessem em mente que somente a autora poderia continuar a escrita, o consenso do que deveria ser escrito foi proposto pelo grupo, e a autora apenas seguiu o direcionamento. Esse tipo de interação se assemelha à estratégia descrita por P. Lowry, Curtis e M. Lowry (2004) como group single-author writing, quando uma única pessoa é responsável por escrever em nome do grupo.

"A encomenda", terceiro conto compartilhado, é sobre Isabel, uma mulher de 27 anos, empreendedora e destemida. Em uma noite, durante uma conversa entre amigos, surge a

3 Por cuidados éticos, os nomes dos sujeitos são fictícios e foram sugeridos pelos próprios alunos. 
oportunidade de ela expandir seus serviços on-line para Portugal. Depois de muito hesitar, ela decide partir. Porém, chegando a Lisboa, Isabel é abordada no aeroporto por policiais. Eles alegam que há algo errado em sua mala e que ela está envolvida com o tráfico internacional de drogas. O conto chega ao fim com Isabel sendo algemada e levada para uma viatura. A história deixa várias dúvidas no ar, principalmente em relação aos "negócios" com que a protagonista trabalhava.

A segunda versão do conto chegou à discussão em grupo cheia de lacunas. A autora estava muito empolgada em compartilhar o que já havia escrito e constantemente lançava perguntas para a turma. Vários detalhes de enredo foram acrescentados. A autora esperava pelas sugestões dos colegas. O movimento de discussão foi o inverso do conto de número 2. Notadamente, quem comandou a discussão foi a autora. Apesar de não sugerir nada, ela fazia, por meio de perguntas, com que os colegas participassem.

O quarto conto, "Desejar, acreditar, realizar", narra a história de cinco crianças pequenas que encontram um poço dos desejos. Cada uma delas faz um desejo e todos vão embora. No dia seguinte, ao voltarem, percebem que o poço havia sumido. Anos mais tarde, os amigos o reencontram no mesmo lugar. Quase todos fazem novos desejos, que são atendidos, e, com isso, o conto se encerra. Essa narrativa já chegou "finalizada" para a terceira etapa da dinâmica. O autor abriu a discussão relatando como foi o processo de escrita, em que se inspirou e por que pensou em escrever a história. Os colegas não discutiram questões temáticas, mas houve algumas intervenções linguísticas. O autor estava engajado e interessado, mas o grupo, não. O assunto não pareceu despertar tanto interesse, e isso fez com que a turma deixasse de alimentar a discussão.

O conto "Ponteiros Banzeiros: eiras, beiras" remeteu a lembranças amorosas embaraçadas pela desilusão ou pela esperança do reencontro. O autor, com muita destreza, fez contrapontos entre a leveza do momento e o peso do passado. A discussão sobre o texto, no entanto, foi muito truncada. A linguagem usada pelo autor dificultou o entendimento sobre o conteúdo. Nenhuma intervenção ocorreu. O autor do conto, por ser tímido, não se abriu e não deu muitos detalhes sobre sua composição. O leitor beta, no momento da discussão, relatou que encontrou dificuldades de vocabulário, e o restante da turma ficou dividida entre aqueles que defendiam uma "escrita mais inteligível" e aqueles que defendiam a ideia de que o conto completava o sentimento de inquietação e complexidade que o personagem parecia vivenciar. Ao final, os alunos entraram em um consenso e ficou decidido que o conto iria permanecer com a mesma linguagem.

Essa segunda sessão de análises nos revelou aspectos contrários aos presentes na primeira etapa da dinâmica. As discussões em grupo propiciaram um tipo de interação bem diferente da que ocorreu na etapa em que os leitores beta intervieram no texto de forma individual. Assim como as coordenadas dadas na primeira etapa, o propósito da segunda etapa da dinâmica também era de intervir no texto do colega, na intenção de melhorá-lo e dar continuidade à escrita, se fosse o caso. Com base no que ocorreu durante as discussões em grupo, notamos que o número de intervenções que priorizam os aspectos de enredo superou consideravelmente o de intervenções de caráter puramente gramatical, o que nos leva a crer que são tipos de intervenções que se complementam, sendo que ambas favorecem o processo de construção dos textos.

O gênero conto literário foi um disparador interessante e que motivou os alunos a participarem da dinâmica, porém não foi eficaz o bastante, em alguns casos, para manter o interesse dos alunos até o fim do processo. Uma estratégia interessante para esse tipo de dinâmica pode ser realizar a escolha das temáticas em grupo, antes de começar o processo de escrita, para que haja interação efetiva, durante todo o processo, devido à existência de consenso desde o início do trabalho (LOWRY, P.; CURTIS; LOWRY, M., 2004). 


\section{Percepções dos produtores de texto sobre a escrita colaborativa}

Aqui discutiremos as respostas dos participantes a um questionário, aplicado ao final da dinâmica, cujo objetivo foi investigar a percepção deles em relação ao processo de EC. Todos os respondentes sinalizaram como positivo o fato de terem recebido retorno sobre sua produção, e isso também foi apontado como fator de estímulo para que o texto fosse desenvolvido. Discutir as ideias com o grupo foi considerado divertido e proveitoso, e o dinamismo da proposta de atividade foi visto como algo que estimula a habilidade de escrever, de acordo com um respondente: "Foi muito divertido e proveitoso discutir as demais ideias do grupo. Cada um com uma ideia diferente, contribuições diversas e certamente um ambiente leve e divertido. Cada história ali, que poderia ser individual, se tornou um trabalho do grupo, de certa forma" A discussão foi vista como a etapa mais significativa do processo. A oportunidade de expor dúvidas e opiniões e ouvir o que os colegas tinham a dizer foi apontada como fator positivo, conforme a afirmação de outro respondente: "Me ajudou a não ter medo do que os outros vão dizer sobre o que vc escreve, sendo bom, ou ruim, mas sempre será construtivo"

Quanto aos critérios utilizados para escolher um conto a ser betado, os participantes ficaram divididos entre selecionar pela temática ou pelo grau de proximidade com o autor do texto. Eles também foram solicitados a responder sobre as contribuições feitas pelo leitor beta, que lhes pareceram sempre pertinentes e aceitáveis. Outras percepções advieram da experiência de compartilhar e comentar textos em processo, de modo geral de maneira positiva. Disse uma estudante: "Me senti empoderada para escrever mais" Enquanto outro respondeu: "Percebi que tenho muito apego às minhas criações e, por vezes, fica difícil não levar para o lado pessoal, rs. Mas é algo a ser trabalhado, porque o texto só melhora". A consciência de grupo, um dos pilares da escrita de fanfictions, foi, de certa forma, apropriada pelos participantes. Assim como nos textos que fazem parte de fandoms, discutir os contos literários colaborativamente gerou um sentimento de pertencimento.

\section{Finalmente...}

Tendo em mente que o trabalho com a produção escrita é algo vivido por professores desde a Educação Básica até o Ensino Superior, acreditamos ser necessário refletir sobre possíveis alternativas para o engajamento dos autores na produção textual. Em que sentido as fanfictions e seus processos de produção, sempre muito vibrantes e producentes, poderiam contribuir para a escrita em ambiente acadêmico? Pesquisas como as de Paris (2016) e Alves (2015) relatam a utilização de fanfiction em sala de aula para discutir questões relativas à descrição de práticas de letramento dos jovens. Ao lançar um olhar sobre esses estudos, percebe-se que o engajamento na produção de textos nesses ambientes ocorre, principalmente, porque os envolvidos compartilham os mesmos assuntos e gostos, a ponto de se sentirem motivados a escrever e ler juntos. É possível perceber então que, tanto na sala de aula da pesquisadora quanto nos fandoms, há afinidades que motivam a escrita.

No decorrer de nossa pesquisa, aproximamo-nos ainda mais do universo plural e, por vezes, confuso de escrita de textos ficcionais feita por fãs, processo que se reconfigura continuamente. Essa aproximação reforçou ainda mais nossa noção de que o escrever e o publicar fanfictions merece estudo, e que o campo educacional tem muito a ganhar com as descobertas provenientes das pesquisas feitas nessa área, já que os sujeitos precisam se engajar em eventos de letramento cada vez mais modernos e diversificados, novos em relação às práticas institucionalizadas.

Nossa intenção de contribuir para essa aproximação envolveu uma proposta de EC inspirada em processos existentes no universo das fanfictions, tendo em vista que a complexidade da EC se manifesta nas complexidades sociais, intelectuais e de procedimento (LOWRY, P.; CURTIS; 
LOWRY, M., 2004). Assim sendo, ao analisar os textos produzidos colaborativamente e os processos de escrita dos alunos, foi possível, num primeiro momento, evidenciar o predomínio de intervenções de caráter textual/gramatical por parte dos beta leitores, enquanto, na segunda etapa da dinâmica, os participantes betaram os textos oralmente e colaboraram mais profundamente para o progresso de escrita dos contos.

As análises das respostas ao questionário demonstraram que a interação foi um aspecto bem avaliado pelos sujeitos. Também é possível dizer que a dinâmica de EC foi uma experiência positiva para a maioria deles, que, em geral, atuaram num esquema de group single-author writing (LOWRY, P.; CURTIS; LOWRY, M., 2004). É importante destacar que o estudo apresenta suas limitações, tanto porque não propõe outras estratégias de EC, quanto porque o assunto de cada conto influenciou na forma como a discussão em grupo ocorreu. Acreditamos, a partir disso, que escolher as temáticas previamente pode ser mais produtivo. São alinhamentos sempre possíveis, quando estamos abertos à reconfiguração dos processos e a elementos que só podemos verificar ad hoc.

Cremos que os resultados obtidos permitem uma reorganização da taxonomia de P. Lowry, Curtis e M. Lowry (2004) quanto aos papéis de escritor, consultor, editor, revisor, líder do grupo e facilitador, em contexto de fanficwriting. O leitor beta é um participante das comunidades de fanfictions que merece seu posto entre os categorizados nas atividades que envolvam a EC, mas com uma atuação muito mais fluida e múltipla, conforme a necessidade das etapas de produção do texto. Ademais, acreditamos que o estudo aqui relatado reúne elementos que podem contribuir para que professores e alunos se sintam motivados a repensar o modo como trabalham com a escrita, na sala de aula ou fora dela, e dar espaço para novos modos de produção textual que surgem em contextos como o das fanfictions. Consideramos possível aplicar a dinâmica elaborada aqui na produção de outros gêneros textuais, de forma que os envolvidos se sintam protagonistas, motivados e, acima de tudo, que façam da competência de escrever combustível para transformar suas vidas.

\section{Referências}

ALMEIDA, Mariana Rodrigues Montenegro de et al. Self-publishing como escolha ativa: como o marketing de e-books é desenvolvido nesse cenário. 2016. 57 f. Dissertação (Mestrado em Educação) - Universidade de Coimbra, Coimbra, 2016.

ALVES, Waldinéia Lemes da Cruz. Letr@mento no universo fanfiction: do impresso à tela. 2015. 120 f. Dissertação (Mestrado em Estudos de Linguagem) - Universidade Federal de Mato Grosso, Mato Grosso, 2015.

CARVALHO, C. R. A escrita colaborativa no ensino superior. In: EDUCERE - CONGRESSO NACIONAL DE EDUCAÇÃO, 12., 2015, Curitiba. Formação de Professores, Complexidade, Trabalho docente. Anais... Curitiba: PUCPR, 2015. p. 10.345-10.355.

CASTILHO, Wagner Francisco et al. Escrita coletiva: cabeças distantes, conhecimentos articulados. In: CONGRESSO DA ASSOCIAÇÃO BRASILEIRA DE EDUCAÇÃO A DISTÂNCIA. Anais... 2007.

CLEMENTE, Bianca Jussara Borges. O gênero digital fanfiction e a modernidade líquida. Revista EducaOnline. Rio de Janeiro, v. 10, n. 2, p. 104-118, 2016.

CORCELLES, M. et al. Enseñar a escribir un artículo de investigación mediante na revisión colaborativa: percepciones de los estudantes. Revista Signos, Chile, v. 50, n. 95, p. 337-360, 2017.

COSTA, Fernando Albuquerque; CARVALHO, Ana Amélia Amorim. WebQuests: oportunidades para alunos e professores. Actas do Encontro sobre WebQuest, p. 8-25, 2006. 
COSTA, M. J.; BULHÕES-CAMPOS, Jailma. Reflexões sobre a apropriação pedagógica do gênero digital Fanfiction para práticas de leitura e escrita, A Palavrada, Bragança, v. 4, p. 57, 2013.

CRUZ, R. R. Fanfiction: impulsionando prática de leitura em tela e produção textual entre adolescentes. In: SIMPÓSIO HIPERTEXTO E TECNOLOGIAS NA EDUCAÇÃO - multimodalidade e ensino. Anais Eletrônicos, Recife, p. 1-16, 2008.

FARACO, C. A. Apresentação. In: GUEDES, Paulo Coimbra. Da redação à produção textual. São Paulo: Parábola Editorial, 2009. p 2-3.

FERRAREZI JR, Celso; CARVALHO, Robson Santos de. Produzir textos na educação básica: o que saber, como fazer. São Paulo. Parábola Editorial, 2015. 224 p.

GEE, J. P. The new literacy studies: from "socially situated" to the work of the social. In: BARTON, D.; HAMILTON, M.; IVANIC, R. (ed.). Situated literacies: reading and writing in context. London: Routledge, 2000. p. 180-196.

GEE, J. P. What video games have to teach us about learning and literacy. Computers in Entertainment (CIE), University of Wisconsin-Madison, v. 1, n. 1, p. 20-20, 2003.

JENKINS, Henry. Textual poachers: studies in culture and communication. Abingdon-Onthames: Routledge, 1992.

JENKINS, Henry. Invasores do texto: fãs e cultura participativa. Nova Iguaçu, RJ: Marsupial, 2015. KNOBEL, Michele; LANKSHEAR, Colin. Studying new literacies. Journal of Adolescent \& Adult Literacy, Newark, v. 58, n. 2, p. 97-101, 2014.

LACERDA, Tiago de Oliveira. Fanzines: uma faceta da comunicação alternativa na cidade de Campina Grande. 2008. 58 f. Trabalho de Conclusão de Curso (Graduação em Comunicação Social) - Universidade Estadual da Paraíba, Paraíba, 2008.

LANKSHEAR, C. Literacies studies in education. In: PETERS, M. (org.). After the disciplines: the emergence of cultural studies. Westport, CT: Bergin \& Garvey, 1999. p. 99-227.

LANKSHEAR, Colin; KNOBEL, Michele. New literacies: changing knowledge and classroom learning. Open University Press, 2003.

LANKSHEAR, Colin; KNOBEL, Michele. New literacies: everyday practices and classroom learning. 2. ed. Glasglow: McGraw-Hill/Open University Press, 2006.

LANKSHEAR, Colin; KNOBEL, Michele. A new literacies reader. New York: Open University Press, 2011.

LEANDRO, Diêgo Cesar; WEISSHEIMER, Janaína; COOPER, Jennifer Sarah. Escrita colaborativa em Inglês como Língua Adicional: produção on-line e presencial em contexto universitário. Hipertextus Revista Digital, Recife, v. 10, p. 1-18, 2013.

LOPES, Iveuta de Abreu. Cenas de letramentos sociais. 2004. 212 f. Tese (Doutorado em Linguística) - Centro de Artes e Comunicação, Universidade Federal de Pernambuco, Pernambuco, 2004.

LOWRY, P.; CURTIS, A.; LOWRY, M. Building a taxonomy and nomenclature of collaborative writing to improve interdisciplinar research and practice. Journal of Business Communication, Washington, v. 41, n. 1, p. 66-99, 2004. Disponível em: <http://journals.sagepub.com/doi/ abs/10.1177/0021943603259363>. Acesso em: 2 out. 2017.

MIRANDA, Fabiana Móes. Fandom: um novo sistema literário digital. In: FERREIRA, Ermelinda Maria Araújo (org.). Intersecções: ciência e tecnologia, literatura e arte. Recife: Edufpe, 2009. p 1 -21 .

MOLL, L. C. Vygotsky e a educação: implicações pedagógicas da psicologia sócio-histórica. Porto Alegre: Artes Médicas, 1996.

NEVES, André de Jesus. A literatura marginal na internet: o fenômeno fanfiction como instrumento de 
disseminação e divulgação das/nas margens. Pontos de Interrogação: Revista de Crítica Cultural, Alagoinhas, v. 1, p. 153-166, 2011.

OLIVEIRA, C. F. A cultura de fãs e fandom como perspectiva das práticas participativas de consumo de mídia. In: BULHOES, M.; MORAIS, Osvando J. de. (org.). Ciências da Comunicação: circularidades teóricas e práticas acadêmicas. Sarapuí, SP: OJM Casa Editoria, 2015. p. 630-655.

PAIVA, F. A. Conclusões sobre propostas de escrita colaborativa em wiki. In: SIELP, 4., 2014, Uberlândia-MG. Anais do SIELP, 2014.

PARIS, Larissa Giacometti. Oficina de fanfictions na escola: uma análise das práticas de revisão e reescrita. 2016. 125 p. Dissertação (Mestrado em Letras) - Instituto de Estudos da Linguagem, Universidade Estadual de Campinas, Campinas, SP, 2016. Disponível em: <http://www. bibliotecadigital.unicamp.br/document/?code=000967959>. Acesso em: 20 jul. 2018.

PINHEIRO, Petrilson Alan. A escrita colaborativa por meio do uso de ferramentas digitais: ressignificando a produção textual no contexto escolar. Calidoscópio, Porto Alegre, v. 9, n. 3, p. 226239, 2011.

PIVA, Heidi Campana; AFFINI, Letícia Passos. Apontamentos sobre o conceito de fanfiction. In: X CONFERÊNCIA BRASILEIRA DE MÍDIA CIDADÃ E V CONFERÊNCIA SUL-AMERICANA DE MÍDIA CIDADÃ UNESP, FAAC, Bauru-SP, 22-24 abr. 2015.

RIBEIRO, Ana Elisa. Escrita colaborativa mediada por computador: relato de caso no Brasil. In: LACO, Liliana; NATALE, Lucía; ÁVILA, Mónica (org.). La lectura y la escritura en la formación académica, docente y profesional. Buenos Aires: Editorial de la Universidad Tecnológica Nacional, 2011. v. 1. p. 209-216.

SANTANA, Inácia. A aprendizagem da escrita: estudo sobre revisão cooperada de texto. Porto: Porto Editora, 2007.

SOARES, Magda. Letramento e escolarização. In: RIBEIRO, V. M. (org.). Letramento no Brasil: reflexões a partir do INAF 2001. São Paulo: Global, 2003. p. 89-113. 